\title{
Insights into the mechnisms of the differential abilities of two N2O reducers, Pseudomonas sp., isolated from paddy soil
}

Chunmei Liu ( $\square$ liuchunmei15@mails.ucas.edu.cn )

Institute of Subtropical Agriculture Chinese Academy of Sciences https://orcid.org/0000-0003-42038990

\section{Rong Sheng}

University of Chinese Academy of Sciences

\section{Xing Chen}

University of Chinese Academy of Sciences

Yi Liu

University of Chinese Academy of Sciences

Wenxue Wei

University of Chinese Academy of Sciences

\section{Research Article}

Keywords: Pseudomonas sp., N2O reducing ability, nosZ expression, genomic analysis, paddy soil

Posted Date: July 26th, 2021

DOI: https://doi.org/10.21203/rs.3.rs-719894/v1

License: (c) (1) This work is licensed under a Creative Commons Attribution 4.0 International License. Read Full License 
1 Insights into the mechnisms of the differential abilities of two $\mathrm{N}_{2} \mathrm{O}$ reducers, Pseudomonas sp., 2 isolated from paddy soil

3 Chunmei Liu ${ }^{1,2}$, Rong Sheng ${ }^{1}$, Xing Chen ${ }^{1,2}$, Yi Liu ${ }^{1}$ and Wenxue Wei ${ }^{1 *}$

$4 \quad{ }^{1}$ Key Laboratory of Agro-Ecological Processes in Subtropical Regions and Taoyuan Station of Agro-

5 Ecology Research, Institute of Subtropical Agriculture, Chinese Academy of Sciences, Changsha, China

$6{ }^{2}$ College of Resource and Environment, University of Chinese Academy of Sciences, Beijing, China

7

8 "Corresponding Author

$9 \quad$ Wenxue Wei

10 Institute of Subtropical Agriculture, Chinese Academy of Sciences 644, the second street of yuanda road, 11 Changsha 410125 P.R.China

12 Email: wenxuewei@isa.ac.cn 


\section{Abstract}

Microbial reduction of nitrous oxide $\left(\mathrm{N}_{2} \mathrm{O}\right)$ in soil plays an important role in mitigating $\mathrm{N}_{2} \mathrm{O}$ emission, and it is the only known biological process for $\mathrm{N}_{2} \mathrm{O}$ sink. However, it is not clear about the mechnisms of differential $\mathrm{N}_{2} \mathrm{O}$ reducing function of $\mathrm{N}_{2} \mathrm{O}$ reducers. In this study, the $\mathrm{N}_{2} \mathrm{O}$ reducing activities and nos $Z$ gene transcript abundance of two $\mathrm{N}_{2} \mathrm{O}$ reducers named P. veronii DM15 (DM15) and P. frederiksbergensis DM22 (DM22) were determined under varied temperature and oxygen concentration conditions, as well as the whole genomes were sequenced by Illumina sequencing. The results showed that DM15 generally exhibited significantly higher abilities in $\mathrm{N}_{2} \mathrm{O}$ reduction than DM22 in regardless of low or high temperature and aerobic or anaerobic conditions. Coincidently, DM15 expressed significantly more nos $Z$ gene transcripts under above environments. Genomic analysis further revealed that DM15 possessed about 30\% more transcription related genes than DM22 and the nos cluster of the former contained a transcriptional regulator gene of $d n r$ which not found in that of the later. Additionally, the nos genes of DM15 possessed obviously higher expression potentials (CAI value). In conclusion, the transcriptional regulation of nos gene region would be a crucial factor in determining the differences of $\mathrm{N}_{2} \mathrm{O}$ reducing abilities of the two $\mathrm{N}_{2} \mathrm{O}$ reducing isolates.

Keywords: Pseudomonas sp., $\mathrm{N}_{2} \mathrm{O}$ reducing ability, nos $Z$ expression, genomic analysis, paddy soil 


\section{Introduction}

Nitrous oxide $\left(\mathrm{N}_{2} \mathrm{O}\right)$ is a major greenhouse gas with high warming potential [1] and posing a threat to the global changes [2]. $\mathrm{N}_{2} \mathrm{O}$ consumption is an important process in alleviating $\mathrm{N}_{2} \mathrm{O}$ emission [3, 4]. It was discovered that the only known biological $\mathrm{N}_{2} \mathrm{O}$ sink is denitrification, in which $\mathrm{N}_{2} \mathrm{O}$ is reduced to $\mathrm{N}_{2}$ by nitrous oxide reductase encoded by nos $Z$ gene [5]. In recent years, the community compositions and population size of nosZ-containing bacteria in various ecosystems have been investigated, such as grassland [6], forest [7], farmland [8] and sediment [9]. It was demonstrated that the composition and distribution of nosZ-containing communities were largely determined by soil $\mathrm{pH}$ and other soil properties [10-13], and nos $Z$ abundance was positively related to $\mathrm{N}_{2} \mathrm{O}$ reduction [14]. Such these discoveries are important in understanding the $\mathrm{N}_{2} \mathrm{O}$ consumption and the influenced factors of nosZ-containing communities. Since nos $Z$ community is composed by diverse bacterial species [15], investigation on the mechanisms of $\mathrm{N}_{2} \mathrm{O}$ reduction of nosZ-containing strains would be fundamental for the cognition of $\mathrm{N}_{2} \mathrm{O}$ reducing functions in ecosystems.

The abilities of $\mathrm{N}_{2} \mathrm{O}$ reduction of bacterial strains were influenced by environmental factors including oxygen, temperature, $\mathrm{pH}$ and so on [16, 17]. Oxygen was an important factor [18], generally, anaerobic condition was suitable for the functional performance of $\mathrm{N}_{2} \mathrm{O}$ reducers, high oxygen concentration could significantly limit the $\mathrm{N}_{2} \mathrm{O}$ reductase activity [19]. However, it was also indicated that some aerobic denitrifiers exhibited relatively strong $\mathrm{N}_{2} \mathrm{O}$ reducing efficiency under oxic condition [20, 21], such as Pseudomonas, Azospirillum, Herbaspirillum, Marinobacter [22-26]. The suitable $\mathrm{pH}$ and temperature for $\mathrm{N}_{2} \mathrm{O}$ reducing isolates were between 6-8 and $15-35^{\circ} \mathrm{C}$ [27-30], respectively. Out of these ranges the $\mathrm{N}_{2} \mathrm{O}$ reducing activities were obviously restricted. However, the lack of knowledge about the mechanisms of differential functional performances of $\mathrm{N}_{2} \mathrm{O}$ reducers would limit our understanding of the shifts of $\mathrm{N}_{2} \mathrm{O}$ reducing communities in ecosystems.

As the rapid development of sequencing techniques and bioinformatics in recent years, it is applicable to reveal metabolic pathways and regulating systems by genomic informatics of microbial strains [31]. Therefore, analysis of the genomic characteristics of microorganisms would be curial in understanding their environmental adaptabilities and functions [32]. It was suggested that the activity of $\mathrm{N}_{2} \mathrm{O}$ reductase of nosZ-containing bacteria could be predicted by the analysis of their structural genes of nos clusters, such as $\operatorname{nos} R$, nosD, nosF, nos $Y$, nosL.[33]. Besides, the transcriptional regulators would also play important roles in manipulation of the functional activity of $\mathrm{N}_{2} \mathrm{O}$ reductase, like NarX, NarL, FNR, DNR and so on [34]. So, the genomic characteristics and the regulation system of nos operons could be important in explaining the differences of $\mathrm{N}_{2} \mathrm{O}$ reducing abilities between $\mathrm{N}_{2} \mathrm{O}$ reducers.

In this study, two nosZ-containing isolates named $P$. veronii DM15 (DM15) and $P$. frederiksbergensis DM22 (DM22) were selected, and their $\mathrm{N}_{2} \mathrm{O}$ reducing abilities, nos $Z$ gene expression and whole genome sequences were systematically determined. The objectives were to explore the mechnisms of the differential $\mathrm{N}_{2} \mathrm{O}$ reducing abilities of the selected strains. The results would broaden our knowledge in understanding the community function of $\mathrm{N}_{2} \mathrm{O}$ reducers.

\section{Materials and methods}

\subsection{Isolation and identification of $\mathrm{N}_{2} \mathrm{O}$ reducers}

A paddy soil $(0-15 \mathrm{~cm})$ was collected for denitrifying bacteria isolation in Jiaxing $\left(\mathrm{N}: 30^{\circ} 38^{\prime} 21.6^{\prime \prime}\right.$, E: $\left.120^{\circ} 46^{\prime} 50.9^{\prime \prime}\right)$ in Dec 2014, it had been used for rice production for centuries. Soil denitrifiers were isolated by using enrichment medium $\left(\mathrm{K}_{2} \mathrm{HPO}_{4} 0.5 \mathrm{~g} / \mathrm{L}, \mathrm{MgSO}_{4} \cdot 7 \mathrm{H}_{2} \mathrm{O} 0.2 \mathrm{~g} / \mathrm{L}, \mathrm{Na}_{2} \mathrm{HPO}_{4} \cdot 12 \mathrm{H}_{2} \mathrm{O} 10.5\right.$ $\mathrm{g} / \mathrm{L}, \mathrm{KNO}_{3} 2 \mathrm{~g} / \mathrm{L}$, succinic acid $0.52 \mathrm{~g} / \mathrm{L}$ ). Solid medium was made by adding $15 \mathrm{~g}$ agar per liter liquid 
enrichment medium. Fresh soil ( $20 \mathrm{~g})$ was added to a $250 \mathrm{~mL}$ conical flask with $20 \mathrm{~mL}$ sterile water and then incubated for ten days under $30^{\circ} \mathrm{C}$ and $120 \mathrm{rpm}$ followed by three days without shaking, this process was repeated three times. Afterwards, $1 \mathrm{~mL}$ upper solution was transferred to a new sterile flask containing $30 \mathrm{~mL}$ fresh liquid medium and incubated for $24 \mathrm{~h}$ at $30^{\circ} \mathrm{C}$ and $120 \mathrm{rpm}$ and $100 \mu \mathrm{L}$ of the suspension was plated onto solid medium and cultured overnight at $30^{\circ} \mathrm{C}$, then single colonies was transferred onto a solid medium plate with streaking successively three times to get pure strains.

To screen $\mathrm{N}_{2} \mathrm{O}$ reducers, the genomic DNA of the above isolates was extracted from $2 \mathrm{~mL}$ suspension when the isolates were cultured to the logarithmic stage (after about 12 hours of culturing), using the TIANamp Bacterial DNA Kit. nosZ gene fragment were amplificated and sequenced with nosZF/nosZR primers[35]. Then preliminary functional experiment of $\mathrm{N}_{2} \mathrm{O}$ reduction of the isolates were conducted by cultivation with $179.59 \mu \mathrm{g} / \mathrm{L} \mathrm{N} \mathrm{N}_{2} \mathrm{O}$ and detection of $\mathrm{N}_{2} \mathrm{O}$ consumption. Two $\mathrm{N}_{2} \mathrm{O}$ reducers named $P$. veronii DM15 (DM15) and P. frederiksbergensis DM22 (DM22) were selected for experiment material in this study.

\subsection{Cell preparation and sampling}

Cell culture experiments were designed to test the functional behaviors of the strains under varied oxygen and temperature conditions, the oxygen concentrations were $0 \%, 10 \%, 21 \% \mathrm{O}_{2}$ at $30^{\circ} \mathrm{C}$ and the temperatures were $20^{\circ} \mathrm{C}, 30^{\circ} \mathrm{C}, 40^{\circ} \mathrm{C}$ under $0 \% \mathrm{O}_{2}$. The cell culture was conducted with inoculation of DM15 and DM22 independently, while a no inoculation control was set for each experiment. All the treatments had three replications. The detailed procedures are as follows:

Firstly, the Erlenmeyer flasks containing $30 \mathrm{~mL}$ denitrification medium (DM) inoculated with DM15 and DM22 independently were cultivated for $24 \mathrm{~h}$ at $30^{\circ} \mathrm{C}$ and $150 \mathrm{rpm}$. This DM was prepared as follows[36]: $\mathrm{K}_{2} \mathrm{HPO}_{4} 0.5 \mathrm{~g} / \mathrm{L}, \mathrm{NaH}_{2} \mathrm{PO}_{4} 0.25 \mathrm{~g} / \mathrm{L}, \mathrm{MgSO}_{4} \cdot 7 \mathrm{H}_{2} \mathrm{O} 0.2 \mathrm{~g} / \mathrm{L}, \mathrm{KNO}_{3} 2 \mathrm{~g} / \mathrm{L}$, trisodium citrate $11.35 \mathrm{~g} / \mathrm{L}(\mathrm{C} / \mathrm{N}=10)$, trace element stock solution $500 \mu \mathrm{L} / \mathrm{L}$, pH value 7.0. Afterwards, $1 \mathrm{~mL}$ above broths was transferred into a culture bottle with $30 \mathrm{~mL}$ DM respectively and the bottles were tightly sealed with butyl rubber stoppers and a crimped metal seal. After about $16 \mathrm{~h}$ cultivation $\left(30^{\circ} \mathrm{C}\right.$ and $\left.150 \mathrm{rpm}\right)$ when the cell growth was at logarithm stage and OD600 value reached above 0.5 , the cells were collected by centrifuging at $4000 \mathrm{rpm}$ for $10 \mathrm{~min}$. The pellet was resuspended in $30 \mathrm{~mL} \mathrm{KNO}_{3}$-free $\mathrm{DM}$ followed by twice washes with this solution. Then the OD600 (Bioscreener C, FP-1100-C) of the suspension was adjusted to 0.5 with $\mathrm{KNO}_{3}$-free $\mathrm{DM}$ for each culture and transferred $30 \mathrm{~mL}$ adjusted suspension into a $100 \mathrm{~mL}$ culture bottle.

The sealed bottles were vacuumized and $179.59 \mu \mathrm{g} / \mathrm{L} \mathrm{N} \mathrm{N}_{2} \mathrm{O}$ gas was immediately filled through a $0.22 \mu \mathrm{m}$ sterile filter, then were incubated for $10 \mathrm{~min}$ at $150 \mathrm{rpm}$. For temperature experiment, the incubation was conducted at $20,30,40^{\circ} \mathrm{C}$ under anaerobic condition, independently. For oxygen experiment, the oxygen concentration was controlled as $0 \%, 10 \%, 21 \%$ by filling the bottle space with oxygen and helium.

Cell sampling for RNA analysis was carried out by taking $1 \mathrm{~mL}$ cell suspension before and after the 10 min incubation for all the treatments, the cell samples were flash frozen in liquid nitrogen immediately and total RNA was extracted within $12 \mathrm{~h}$, the RNA samples were stored at $-80^{\circ} \mathrm{C}$. Gas sampling for residue $\mathrm{N}_{2} \mathrm{O}$ concentration determination was performed immediately after the 10 min incubation, $20 \mathrm{~mL}$ gas sample from the upper space of each bottle was collected and stored in a $12 \mathrm{~mL}$ vial (Labco limited high Eycombe, UK).

\subsection{Determination of $\mathrm{N}_{2} \mathrm{O}$ reducing abilities}

$\mathrm{N}_{2} \mathrm{O}$ concentration was measured by a gas chromatograph (Agilent 7890A, USA). $\mathrm{N}_{2} \mathrm{O}$ reducing 
activity was determined by testing the rates of $\mathrm{N}_{2} \mathrm{O}$ reduction of the strains and the rates of $\mathrm{N}_{2} \mathrm{O}$ reduction calculated by the following formula:

$$
\mathrm{N}_{2} \mathrm{O} \text { reduction rate }\left(\mathrm{ng} \mathrm{N}_{2} \mathrm{O} / 10^{8} \text { cells } / \mathrm{min}\right)=\frac{(\mathrm{Cck}-\mathrm{CIn}) * 44 * 100}{22.4} * \frac{273}{273+\mathrm{T}} / \frac{\text { Ycount } * \mathrm{~V}}{10 \mathrm{E} 8 * 10}
$$

In this formula, Cck and CIn were the $\mathrm{N}_{2} \mathrm{O}$ concentrations measured in the no inoculation control and inoculation treatment, respectively. $\mathrm{T}$ was gas measured temperature. Ycount and $\mathrm{V}$ represented the number of cells and the broth volume in incubation, respectively.

Subsequently, the count the number of cells corrected by using flow cytometry (Beckman MoFlo XDP), then drew a standard curve based on the OD600 value and number of cells and the formula followed as:

DM15: $\mathrm{Y}($ counts $/ \mu \mathrm{L})=2.37 \mathrm{E}+07 *$ OD value $-1.35 \mathrm{E}+06\left(\mathrm{R}^{2}=0.99\right)$

DM22: $\mathrm{Y}($ counts $/ \mu \mathrm{L})=2.30 \mathrm{E}+07 *$ OD value $-1.30 \mathrm{E}+06\left(\mathrm{R}^{2}=0.99\right)$

\subsection{Quantification of nos $Z$ transcripts}

Total RNA of the cultured cells was extracted with the TransZol Up Plus RNA Kit (Transgen, China) according to manufacturer's protocol. Then $1 \mu \mathrm{g}$ total RNA was used for cDNA synthesis with the TransScript One-Step gDNA Removal and cDNA Synthesis SuperMix Kit (Transgen, China), the reverse transcription was carried out with the specific primer of nosZR [35]. The qPCR reaction was performed in triplicate in a total reaction volume of $10 \mu \mathrm{L}$ containing $5 \mu \mathrm{L}$ SYBR green mix I, $0.2 \mu \mathrm{L}$ Rox (Takara, Dalian, China), $0.2 \mu \mathrm{L}(10 \mathrm{mmol} / \mathrm{L})$ of both forward and reverse primers (nosZ1126F: 5'-GGG CTB GGG CCR TTG CA-3' '/nosZ1381R: 5'-GAA GCG RTC CTT SGA RAA CTT G-3')[8], $1 \mu$ L of template cDNA, and $\mathrm{ddH}_{2} \mathrm{O}$ was added to $10 \mu \mathrm{L}$. Thermal program was run on the ABI prism 7900 system (Applied Biosystem, USA) following conditions: $95^{\circ} \mathrm{C}, 2 \mathrm{~min}$; 40 cycles of $95^{\circ} \mathrm{C}$ for $15 \mathrm{~s}, 60^{\circ} \mathrm{C}$ for 30 $\mathrm{s}, 72^{\circ} \mathrm{C}$ for $30 \mathrm{~s} ; 40^{\circ} \mathrm{C}$ for $30 \mathrm{~s}$. Standard curve was generated using the plasmid containing the fragment of $n o s Z$ gene and conducted the vitro transcription using the Thermo Scientific TranscriptAid T7 High Yield Transcription Kit (Thermo Scientific). Standard curves were linear $\left(\mathrm{R}^{2}=0.997\right)$ in the range used and amplification efficiency was $98 \%$ for $\operatorname{nos} Z$ gene.

\subsection{Analysis of the complete genome sequences}

Firstly, the genome DNA of DM15 and DM22 was quantified by TBS-380 fluorometer (Turner BioSystems Inc., Sunnyvale, CA), and sequenced using an IlluminaHiSeq 2000 genomic sequencer at Majorbio (Shanghai, China). For Illumina sequencing, the DNA samples were sheared into 400-500 bp fragments using a Covaris M220 Focused Acoustic Shearer, Illumina sequencing libraries were prepared from the sheared fragments using the NEXTflex ${ }^{\mathrm{TM}}$ Rapid DNA-Seq Kit. The prepared libraries were used for paired-end Illumina sequencing $(2 \times 150 \mathrm{bp})$ on an IlluminaHiSeq $X$ Ten. The data generated from Illumina platform were used for bioinformatics analysis. For the assembly and annotation, all the analyses were performed using I-Sanger Cloud Platform (www.i-sanger.com) from Majorbio. An assembly of the clean reads were performed using SOAPdenovo2. For Gene prediction and annotation, Glimmer was used for CDS prediction, tRNA-scan-SE was used for tRNA prediction and Barrnap was used for rRNA prediction (https://github.com/tseemann/barrnap). The predicted CDSs were annotated from NR, Swiss-Prot, Pfam, GO, COG and KEGG database using sequence alignment tools such as BLAST, Diamond and HMMER (http://eddylab.org/software/hmmer3/3.1b2/Userguide.pdf). Average Nucleotide Identity (ANI) is a measure of nucleotide-level genomic similarity between the coding regions of two genomes. The ANI Calculator uses the OrthoANIu algorithm, the ANI value results is 
obtained through the website (https://www.ezbiocloud.net/tools/ani). Additionally, an effective method of examining synonymous codon usage bias is the codon adaptation index (CAI) value[37], which was calculated with the EMBOSS V6.6.0.0 software. The codon usage table using the Epsesm.cut (Species name: Pseudomonas syringaepvtomatostr DC3000), and the path of codon database was EMBOSS6.6.0/emboss/data/CODONS.

\subsection{Statistical analysis}

One-way analysis of variance (ANOVA) was used to assess the significant difference in the $\mathrm{N}_{2} \mathrm{O}$ reducing rates and abundance of nos $Z$ transcripts under various temperature and oxygen concentrations. Pearson correlation analysis was employed to quantify the linear relationships between the $\mathrm{N}_{2} \mathrm{O}$ reducing rates and its nos $Z$ transcript copies. ANOVAs and Pearson correlation analysis were performed with SPSS software (SPSS Inc., Chicago, IL). The least significant difference (LSD) was used for multiple comparisons among treatments. Statistical significance was determined at $p<0.05$.

\section{Results}

\subsection{Morphological and General genomic features}

Morphologically, both DM15 and DM22 possessed smooth colony surface and white with slight yellowish color. Meanwhile, both strains were rod-shaped, lacking flagella and non-spore-forming tested with scanning electron microscopy (Fig.S1). In addition, the complete genome sequence of the two strains were deposited at DDBJ/ENA/GenBank under the accession number JAARMA000000000 and JAAUOE000000000. Genomic features of DM15 and DM22 were summarized in Table 1. The ANI (Average Nucleotide Identity) value showed that the similarity between the genomic sequences of the strains was $81.72 \%$. According to the sequence data, DM15 contained 6,646,098 total base pairs with GC content of $60.69 \%$, while DM22 possessed 5,957,529 bp with 59.57\% GC content. The predicted gene numbers of DM15 were 6018, while that of the DM22 were only 5386.

\section{2 $\mathrm{N}_{2} \mathrm{O}$ reducing abilities}

Temperature significantly influenced the $\mathrm{N}_{2} \mathrm{O}$ reducing capabilities of both DM15 and DM22 strains under anaerobic condition (Fig. 1A). The results showed that DM15 possessed significantly stronger $\mathrm{N}_{2} \mathrm{O}$ reducing activity than DM22 throughout all the testing temperatures. The maximum differences appeared at $20^{\circ} \mathrm{C}$ while the $\mathrm{N}_{2} \mathrm{O}$ reduction rate of DM15 was about 5.3 times higher than DM22, and the minimum variances occurred at $30^{\circ} \mathrm{C}$ while the difference reduced to 1.6 times. More interestingly, the function of these two $\mathrm{N}_{2} \mathrm{O}$ reducers differently responded to the changes of temperature, the $\mathrm{N}_{2} \mathrm{O}$ reduction rate of DM15 were positively related to temperature, it significantly increased $86 \%$ from $20^{\circ} \mathrm{C}$ to $30^{\circ} \mathrm{C}$ and slightly increased from $30^{\circ} \mathrm{C}$ to $40^{\circ} \mathrm{C}$ without significance. However, DM22 showed a differed pattern, its rate of $\mathrm{N}_{2} \mathrm{O}$ reduction was very low at $20^{\circ} \mathrm{C}$ with $3.6 \mathrm{ng} \mathrm{N} \mathrm{N}_{2} \mathrm{O} / 10^{8}$ cells $\cdot \mathrm{min}^{-1}$, when temperature was increased from $20^{\circ} \mathrm{C}$ to $30^{\circ} \mathrm{C}$, the rate raised from 3.6 to $21.75 \mathrm{ng} \mathrm{N}{ }_{2} \mathrm{O} / 10^{8}$ cells $\cdot \mathrm{min}^{-1}$, but it quickly decreased to $12.38 \mathrm{ng} \mathrm{N} 2 \mathrm{O} / 10^{8}$ cells $\cdot \mathrm{min}^{-1}$ at $40^{\circ} \mathrm{C}$. Therefore, based on the functional responses of DM15 and DM22 towards temperature, the former expressed strong $\mathrm{N}_{2} \mathrm{O}$ reducing activities under the testing temperatures.

The $\mathrm{N}_{2} \mathrm{O}$ reduction rates of DM15 and DM22 responded to the change of $\mathrm{O}_{2}$ levels were observed (Fig. 1B). It was detected that the highest $\mathrm{N}_{2} \mathrm{O}$ reducing capacities of both DM15 and DM22 appeared under anaerobic, which were 32.39 and $21.40 \mathrm{ng} \mathrm{N} 2 \mathrm{O} / 10^{8}$ cells $\cdot \mathrm{min}^{-1}$, respectively, the former was significantly higher than the later. Although these strains belong to the same genus, they possessed varied strategies towards increasing oxygen environment. The $\mathrm{N}_{2} \mathrm{O}$ reducing activity of DM15 was much more 
sensitive to low level $(10 \%)$ of $\mathrm{O}_{2}$, it steeply dropped approximately $85 \%$ compared to anaerobic condition, while DM22 only reduced about $60 \%$. Further increasing $\mathrm{O}_{2}$ to $21 \%$ caused continuous decrease of $\mathrm{N}_{2} \mathrm{O}$ reducing activity of both strains, while the rates of DM15 and DM22 dropped 33\% and $83 \%$ the later almost lost its $\mathrm{N}_{2} \mathrm{O}$ reducing function under aerobic environment.

\subsection{Abundance of nos $Z$ transcripts}

The results indicated that the copy numbers of nos $Z$ transcripts of DM15 and DM22 were obviously affected by temperature (Fig. 2A). The abundance of nos $Z$ transcripts of DM15 was 3.94, 3.35, 2.50 folds higher than that of DM22 at $20^{\circ} \mathrm{C}, 30^{\circ} \mathrm{C}, 40^{\circ} \mathrm{C}$, respectively. Both strains exhibited that their highest expressions of nos $Z$ occurred at $30^{\circ} \mathrm{C}$, which were significantly more than that $20^{\circ} \mathrm{C}$ and $40^{\circ} \mathrm{C}$, correspondingly, except for DM22 between $30^{\circ} \mathrm{C}$ and $40^{\circ} \mathrm{C}$. The abundance of nos $Z$ transcripts of either $\mathrm{DM} 15$ or DM 22 at $20^{\circ} \mathrm{C}$ was the lowest.

It was also observed that the expression of nos $Z$ gene in both DM15 and DM22 were seriously inhibited by the increasing oxygen (Fig. 2B). The abundance of nos $Z$ transcripts of both strains was on their top levels under anaerobic condition, but DM15 had significantly higher nos $Z$ transcripts $(2.06 \mathrm{E}+07$ copies per $\mu$ g RNA) than that of DM22 (8.32E+06 copies per $\mu$ g RNA). Compared to DM22, the inhibiting effect of $10 \% \mathrm{O}_{2}$ on the expression of nos $Z$ of DM15 was much more severe, its abundance dropped $74.8 \%$ whereas the former only decreased $33.1 \%$ but there was no significant difference between the strains. Further exposed to $21 \% \mathrm{O}_{2}$, the nos $Z$ transcripts of DM15 did not shift obviously in comparison with that under $10 \% \mathrm{O}_{2}$, but it was decreased about $74.9 \%$ in DM22, indicating DM22 was more sensitive to aerobic condition.

Furthermore, the $\mathrm{N}_{2} \mathrm{O}$ reducing activities of DM15 were not significantly correlated to its nos $Z$ transcript copy numbers on temperature regime $(p=0.657)$, but significantly correlated to that under oxygen treatments $\left(p=0.966^{* *}\right)$. This ability of DM22 was significantly related to the expression of nos $Z$ gene under both temperature and oxygen testing regimes $\left(p=0.804^{* *}, p=0.896^{* *}\right)$.

\subsection{Functional genes annotation}

All putative protein coding sequences were searched against the COG databases (clusters of orthologous groups of proteins). Among the 25 COG categories, the gene sequences of DM15 and DM22 were annotated into 21 categories (Fig. 3), and the former generally consisted of more gene numbers in all the categories than the later. Among the categories, the gene numbers of several categories related to transcription and metabolisms indicated that DM15 contained obviously more than DM22, such as DM15 had 104 more gene numbers of [K] (transcription), 45 more of [E] (amino acid transport and metabolism) and 7 more of [J] (Translation, ribosomal structure and biogenesis) than DM22. It was suggested that DM15 may have the advantages in transcription and translating process.

\subsection{Gene compositions related to nitrogen metabolism}

The genes of DM15 and DM22 were annotated linked to nitrogen metabolism pathways based on KEGG analysis (Fig. 4). It exhibited that the compositions of nitrogen metabolism related genes were similar between them. Firstly, both DM15 and DM22 contained narG/H/I/J, nirB/D, and nas $A / B$ for the dissimilatory/assimilatory nitrate reduction to promote the conversion of nitrate to nitrite or ammonia. Secondly, they carried the complete denitrification genes, including narG/H/I, nirS, norB/C and nosZ, indicating that both strains were typical denitrifying bacteria. In addition, both DM15 and DM22 had no nitrogen-fixing genes, and the genes involved in nitrification contained only nor . It suggesting that the composition of nitrogen cycling genes in these $\mathrm{N}_{2} \mathrm{O}$ reducers was similar. 


\subsection{Gene compositions of nos clusters and predicted nos gene expression potentials}

The annotation information of the genes in the nos regions of DM15 and DM22 was listed in Fig. $5 \mathrm{~A} \& \mathrm{~B}$. The expressivity of $\mathrm{N}_{2} \mathrm{O}$ reductase was indirectly assessed by calculating the CAI values of the genes in nos cluster (Fig. 5C). The nos regions of DM15 and DM22 similarly comprised six functionally assigned genes, including nos $R$, nos $Z$, nosD, nos $F$, nos $Y$ and nosL. Additionally, the FNR binding site and promotor were both predicted in their nos cluster. What the difference was, a $d n r$ gene was detected in the nos region of DM15 but not in that of DM22. DNR, an FNR-related transcriptional regulator for the expression of denitrification genes. Comparing to the CAI values of the reference gene of $r p s R$, the nos genes of both DM15 and DM22 were predicted with high expression potentials. The CAI values indicated that the nos genes of DM15 possessed obviously higher expressivities than that of DM22, especially for the nos $Z$ gene, the CAI value of DM15 was 0.831 , which was the highest and about $6 \%$ higher than DM22.

\section{Discussion}

Among soil denitrifiers, Pseudomonas sp. are testified as typical denitrifying bacteria in various environments [38]. Although previous studies revealed that Pseudomonas strains showed different nitrate removal efficiencies in wastewater and bioreactors [25, 39], and nos $Z$ gene expression could be influenced by environmental factors [16, 17, 29, 40], little was known about the functional difference and the driving mechanisms between $\mathrm{N}_{2} \mathrm{O}$ reducers.

In the present study, it was observed that although DM15 and DM22 belong to the same genus of Pseudomonas, they performed significantly different $\mathrm{N}_{2} \mathrm{O}$ reducing abilities. Since it has been reported that environmental factors could lead to the functional differentiations of denitrifying bacteria, such as temperature, oxygen level, $\mathrm{pH}$ and $\mathrm{C} / \mathrm{N}$ [23, 26, 29, 30], whether the functional difference of these strains was related to environmental conditions? The results of the present study indicated that either under anaerobic and aerobic or varied temperature conditions, DM15 regardless performed higher $\mathrm{N}_{2} \mathrm{O}$ reducing ability than DM22, which suggested that environmental factors would not be the main reason for their differential $\mathrm{N}_{2} \mathrm{O}$ reducing abilities. Thus, the functional differentiation of DM15 and DM22 would be linked to their inner regulations systems.

Based on genomic characters, several possibilities would be linked to $\mathrm{N}_{2} \mathrm{O}$ reduction, such as the gene compositions of nitrogen cycling, nos operons and their regulation systems [41, 42]. The gene composition involved in nitrogen cycling could be important and the difference of other genes compositions in denitrification would influence $\mathrm{N}_{2} \mathrm{O}$ reduction due to variance of the substrate's concentration $[43,44]$. It was detected in the present study that the genes composition of DM15 in the nitrogen cycle, including the dissimilatory /assimilatory nitrate reduction, denitrification, and all other related processes (Figure 4), was the same as DM22, which indicated that the nitrogen cycling genes composition might not be the main force to induce their function difference and it's more likely to be linked the nos $Z$ gene transcriptional regulation.

Normally, an operon consists of promotor(s), structural genes and regulator genes. It was observed in this study that DM15 and DM22 contained the same composition of nos structural genes in their nos cluster regions $[33,45]$, but different regulation systems. The difference was that the regulator gene of $d n r$ presented in the nos cluster of DM15 but not in DM22. Since $d n r$ encodes DNR which was the $\mathrm{Crp} /$ Fnr family transcriptional regulator, it can regulate the nos genes transcription and activate the nos $R$ promotor $[34,46]$. So, the presence of $d n r$ gene in the nos cluster of DM15 would suggest that the expression of its $n o s Z$ gene could be stronger. Actually, the advantage of transcriptional related genes 
and the actual abundance of nos $Z$ transcript also provide the evidences for supporting the above speculation. Additionally, the prediction of nos genes expression by CAI values [47] further indicated that DM15 possessed the stronger expressed potential than DM22. Thus, the existence of $d n r$ gene in the nos cluster of DM15 would be strongly linked to the stronger $\mathrm{N}_{2} \mathrm{O}$ reducing abilities in comparison with DM22.

In conclusion, the strains of $P$. veronii DM15 and $P$. frederiksbergensis DM22, exhibited obviously different $\mathrm{N}_{2} \mathrm{O}$ reducing abilities, and the transcriptional regulation of nos gene region would play a significant role in explaining these differences of $\mathrm{N}_{2} \mathrm{O}$ reducing abilities of the two $\mathrm{N}_{2} \mathrm{O}$ reducing isolates.

\section{Acknowledgements}

These efforts were supported by the National Key Research and Development Program of China (2016YFD0200307) and National Science Foundation of China (grant numbers 41771300, 41501277, 41330856). We would like to thank Professor Laurent Philippot for some suggestions and English language modification to this manuscript.

\section{AUTHORS' CONTRIBUTIONS}

Wenxue Wei, Rong Sheng and Chunmei Liu planned and designed the research; Chunmei Liu and Xing Chen performed the bio-assays; Chunmei Liu and Yi Liu analyzed the genomic data; Chunmei Liu interpreted the data and wrote the manuscript; Wenxue Wei and Rong Sheng modified the manuscript.

\section{Conflict of Interest}

307 


\section{References:}

1. Regan K, Kammann C, Hartung K, Lenhart K, Müller C, Philippot L, Kandeler E, Marhan SJGCB (2011) Can differences in microbial abundances help explain enhanced $\mathrm{N}_{2} \mathrm{O}$ emissions in a permanent grassland under elevated atmospheric $\mathrm{CO}_{2}$ ? GLOBAL CHANGE BIOLOGY 17: 3176-3186.

2. Hofmann DJ, Butler JH, Dlugokencky EJ, Elkins JW, Masarie K, Montzka SA, Tans P (2006) The role of carbon dioxide in climate forcing from 1979 to 2004: introduction of the Annual Greenhouse Gas Index. Tellus Series B-Chemical and Physical Meteorology 58: 614-619. doi: 10.1111/j.1600-0889.2006.00201.x

3. Syakila A, Kroeze, Slomp,Caroline P. (2010) Neglecting sinks for $\mathrm{N}_{2} \mathrm{O}$ at the earth's surface: does it matter? Journal of Integrative Environmental Sciences 7: 79-87.

4. Wang L, Sheng R, Yang HC, Wang Q, Zhang WZ, Hou HJ, Wu JS, Wei WX (2017) Stimulatory effect of exogenous nitrate on soil denitrifiers and denitrifying activities in submerged paddy soil. Geoderma 286: 64-72. doi: 10.1016/j.geoderma.2016.10.023

5. Wang C, Zhu G, Wang Y, Wang S, Yin C (2013) Nitrous oxide reductase gene (nosZ) and $\mathrm{N}_{2} \mathrm{O}$ reduction along the littoral gradient of a eutrophic freshwater lake. J Environ Sci (China) 25: 44-52. doi: 10.1016/s1001-0742(12)60005-9

6. Cantarel AAM, Bloor JMG, Pommier T, Guillaumaud N, Moirot C, Soussana JF, Poly F (2012) Four years of experimental climate change modifies the microbial drivers of $\mathrm{N}_{2} \mathrm{O}$ fluxes in an upland grassland ecosystem. Global Change Biology 18: 2520-2531. doi: 10.1111/j.13652486.2012.02692.x

7. Majeed MZ, Miambi E, Barois I, Bernoux M, Brauman A (2018) Characterization of $\mathrm{N}_{2} \mathrm{O}$ emissions and associated microbial communities from the ant mounds in soils of a humid tropical rainforest. Folia Microbiol (Praha) 63: 381-389. doi: 10.1007/s12223-017-0575-y

8. Chen Z, Liu J, Wu M, Xie X, Wu J, Wei W (2012) Differentiated response of denitrifying communities to fertilization regime in paddy soil. Microb Ecol 63: 446-459. doi: 10.1007/s00248-011-9909-5

9. Minghong Gao, Jiwen Liu, Yanlu Qiao, Meixun Zhao, Xiao-Hua Zhang (2017) Diversity and Abundance of the Denitrifying Microbiota in the Sediment of Eastern China Marginal Seas and the Impact of Environmental Factors. Microbial Ecology 73: 602-615.

10. Domeignoz-Horta LA, Spor A, Bru D, Breuil MC, Bizouard F, Leonard J, Philippot L (2015) The diversity of the $\mathrm{N}_{2} \mathrm{O}$ reducers matters for the $\mathrm{N}_{2} \mathrm{O}: \mathrm{N}_{2}$ denitrification end-product ratio across an annual and a perennial cropping system. Front Microbiol 6: 971. doi: 10.3389/fmicb.2015.00971

11. Castellano-Hinojosa A, Gonzalez-Lopez J, Bedmar EJ (2018) Distinct effect of nitrogen fertilisation and soil depth on nitrous oxide emissions and nitrifiers and denitrifiers abundance. Biology and Fertility of Soils 54: 829-840. doi: 10.1007/s00374-018-1310-9

12. Xing XY, Xu HF, Zhang WZ, Hou HJ, Qin HL, Liu Y, Zhang LM, Fang YT, Wei WX, Sheng R (2019) The characteristics of the community structure of typical nitrous oxide-reducing denitrifiers in agricultural soils derived from different parent materials. Applied Soil Ecology 142: 8-17. doi: 10.1016/j.apsoil.2019.05.013

13. Xiaoya Xu YL, Bhupinder Pal Singh, Qi Yang, Qichun Zhang,Hailong Wang, Zhidan Xia, Hongjie Di, Brajesh K. Singh, Jianming Xu, Yong Li (2020) Nos Z clade II rather than clade I determine in situ $\mathrm{N}_{2} \mathrm{O}$ emissions with different fertilizer types under simulated climate change 
and its legacy. Soil Biology and Biochemistry 150: 1-6.

14. Domeignoz-Horta Luiz A. PL, Peyrard Celine, Bru David, Breuil Marie-Christine, Bizouard Florian, Justes Eric, Mary Bruno, Léonard Joël, Spor Ayme. (2018) Peaks of in situ $\mathrm{N}_{2} \mathrm{O}$ emissions are influenced by $\mathrm{N} 2 \mathrm{O}$-producing and reducing microbial communities across arable soils Global Change Biology 24: 360-370.

15. Jones CM, Graf DR, Bru D, Philippot L, Hallin S (2013) The unaccounted yet abundant nitrous oxide-reducing microbial community: a potential nitrous oxide sink. ISME J 7: 417-426. doi: 10.1038/ismej.2012.125

16. M.Miyahara, S.-W., Kim, S., Fushinobu, K., Takaki, T., Yamada T (2010) Potential of aerobic denitrification by Pseudomonas stutzeri TR2 to reduce nitrous oxide emissions from wastewater treatment plants. APPLIED AND ENVIRONMENTAL MICROBIOLOGY 76: 4619-4625.

17. Tatiana, Kondakova, John, Cronan (2019) Transcriptional regulation of fatty acid cis-trans isomerization in the solvent-tolerant soil bacterium, Pseudomonas putida F1. Environmental Microbiology 21 1659-1676.

18. Toshikazu S, Shohei R, Masaaki H, Akihiko T (2018) Biokinetic Characterization and Activities of N2O-Reducing Bacteria in Response to Various Oxygen Levels. Frontiers in Microbiology 9: 697-707.

19. Stouthamer AH (1991) Metabolic regulation including anaerobic metabolism inParacoccus denitrificans. Journal of bioenergetics and biomembranes 23: 163-185.

20. Miyahara M, Kim SW, Fushinobu S, Takaki K, Yamada T, Watanabe A, Miyauchi K, Endo G, Wakagi T, Shoun H (2010) Potential of Aerobic Denitrification by Pseudomonas stutzeri TR2 To Reduce Nitrous Oxide Emissions from Wastewater Treatment Plants. Applied and Environmental Microbiology 76: 4619-4625. doi: 10.1128/Aem.01983-09

21. Liu Y, Ai GM, Miao LL, Liu ZP (2016) Marinobacter strain NNA5, a newly isolated and highly efficient aerobic denitrifier with zero N2O emission. Bioresour Technol 206: 9-15. doi: 10.1016/j.biortech.2016.01.066

22. Çelen E, Kilic MA (2004) Isolation and Characterization of Aerobic Denitrifiers from Agricultural Soil. Turkish Journal of Biology 28: 9-14.

23. Ji B, Yang K, Zhu L, Jiang Y, Wang HY, Zhou J, Zhang HN (2015) Aerobic denitrification: A review of important advances of the last 30 years. Biotechnology and Bioprocess Engineering 20: 643-651. doi: 10.1007/s12257-015-0009-0

24. He TX, Ye Q, Sun Q, Cai X, Ni JP, Li ZL, Xie DT (2018) Removal of Nitrate in Simulated Water at Low Temperature by a Novel Psychrotrophic and Aerobic Bacterium, Pseudomonas taiwanensis Strain J. Biomed Research International 2018: 1-9. doi: Artn 498408710.1155/2018/4984087

25. Jun KI, Abraham A, Choi O, Sang BI (2019) Aerobic denitrification by a novel Pseudomonas sp. JN5 in different bioreactor systems. Water-Energy Nexus 2: 37-45.

26. Rajta A, Bhatia R, Setia H, Pathania P (2020) Role of heterotrophic aerobic denitrifying bacteria in nitrate removal from wastewater. J Appl Microbiol 128: 1261-1278. doi: 10.1111/jam.14476

27. Jones CM, Allana W, N. TI, Peter D, Bakken LR, Sara H (2011) Phenotypic and genotypic heterogeneity among closely related soil-borne $\mathrm{N}_{2}$ - and $\mathrm{N}_{2} \mathrm{O}$-producing Bacillus isolates harboring the nosZ gene. Fems Microbiology Ecology: 541-552.

28. Liu B, Frostegard A, Bakken LR (2014) Impaired Reduction of $\mathrm{N}_{2} \mathrm{O}$ to $\mathrm{N}_{2}$ in Acid Soils Is Due to a Posttranscriptional Interference with the Expression of nosZ. mBio 5: e01383-01314. 
29. Saleh-Lakha S, Shannon KE, Henderson SL, Goyer C, Trevors JT, Zebarth BJ, Burton DL (2009) Effect of $\mathrm{pH}$ and temperature on denitrification gene expression and activity in Pseudomonas mandelii. Appl Environ Microbiol 75: 3903-3911. doi: 10.1128/AEM.00080-09

30. Zhou Y, Suenaga T, Chuang Q, Hosomi M, Terada A (2021) Temperature and oxygen level determine $\mathrm{N}_{2} \mathrm{O}$ respiration activities of heterotrophic $\mathrm{N}_{2} \mathrm{O}$-reducing bacteria: Biokinetic study. Biotechnology and Bioengineering 118: 1330-1341.

31. Nishizawa T, Tago K, Oshima K, Hattori M, Ishii S, Otsuka S, Senoo K (2012) Complete genome sequence of the denitrifying and $\mathrm{N}_{2} \mathrm{O}$-reducing bacterium Azoarcus sp. strain KH32C. J Bacteriol 194: 1255. doi: 10.1128/JB.06618-11

32. Ormeno-Orrillo E, Menna P, Almeida LG, Ollero FJ, Nicolas MF, Pains Rodrigues E, Shigueyoshi Nakatani A, Silva Batista JS, Oliveira Chueire LM, Souza RC, Ribeiro Vasconcelos AT, Megias M, Hungria M, Martinez-Romero E (2012) Genomic basis of broad host range and environmental adaptability of Rhizobium tropici CIAT 899 and Rhizobium sp. PRF 81 which are used in inoculants for common bean (Phaseolus vulgaris L.). BMC Genomics 13: 735. doi: 10.1186/1471-2164-13-735

33. Sanford RA, Wagner DD, Wu Q, Chee-Sanford JC, Thomas SH, Cruz-Garcia C, Rodriguez G, Massol-Deya A, Krishnani KK, Ritalahti KM, Nissen S, Konstantinidis KT, Loffler FE (2012) Unexpected nondenitrifier nitrous oxide reductase gene diversity and abundance in soils. Proc Natl Acad Sci U S A 109: 19709-19714. doi: 10.1073/pnas.1211238109

34. Spiro S (2012) Nitrous oxide production and consumption: regulation of gene expression by gas-sensitive transcription factors. Philos Trans R Soc Lond B Biol Sci 367: 1213-1225. doi: 10.1098/rstb.2011.0309

35. Rosch C, Mergel A, Bothe H (2002) Biodiversity of denitrifying and dinitrogen-fixing bacteria in an acid forest soil. Applied and Environmental Microbiology 68: 3818-3829. doi: 10.1128/Aem.68.8.3818-3829.2002

36. Wen Y, Wei CH (2011) Heterotrophic nitrification and aerobic denitrification bacterium isolated from anaerobic/anoxic/oxic treatment system. African Journal of Biotechnology 10: 6985-6990.

37. Puigbo P, Bravo IG, Garcia-Vallve S (2008) CAIcal: A combined set of tools to assess codon usage adaptation. Biology Direct 3: 1-8. doi: Artn 3810.1186/1745-6150-3-38

38. Philippot L, Hallin S, Schloter M (2007) Ecology of denitrifying prokaryotes in agricultural soil. Advances in Agronomy, Vol 96 96: 249-305. doi: Doi 10.1016/S0065-2113(07)96003-4

39. Zhang W, Shen J, Zhang H, Zheng C, Wei R, Gao Y, Yang L (2021) Efficient nitrate removal by Pseudomonas mendocina GL6 immobilized on biochar. Bioresour Technol 320: 124324. doi: 10.1016/j.biortech.2020.124324

40. Saleh-Lakha S, Shannon KE, Henderson SL, Zebarth BJ, Burton DL, Goyer C, Trevors JT (2009) Effect of nitrate and acetylene on nirS, cnorB, and nosZ expression and denitrification activity in Pseudomonas mandelii. Appl Environ Microbiol 75: 5082-5087. doi: 10.1128/AEM.0077709

41. Honisch U, Zumft WG (2003) Operon structure and regulation of the nos gene region of Pseudomonas stutzeri, encoding an ABC-Type ATPase for maturation of nitrous oxide reductase. J Bacteriol 185: 1895-1902. doi: 10.1128/JB.185.6.1895-1902.2003

42. Matthias E, Sebastian L, Andrea T, Louisa R, Denitsa E, Rolf D, Elisabeth H, Dieter J (2017) FnrL and Three Dnr Regulators Are Used for the Metabolic Adaptation to Low Oxygen Tension in Dinoroseobacter shibae. Frontiers in Microbiology 8: 642. 
43. Roco CA, Bergaust LL, Bakken LR, Yavitt JB, Shapleigh JP (2017) Modularity of nitrogenoxide reducing soil bacteria: linking phenotype to genotype. Environ Microbiol 19: 2507-2519. doi: $10.1111 / 1462-2920.13250$

44. Bergaust LL, Hartsock A, Liu B, Bakken LR, Shapleigh JP (2014) Role of norEF in denitrification, elucidated by physiological experiments with Rhodobacter sphaeroides. J Bacteriol 196: 2190-2200. doi: 10.1128/JB.00003-14

45. Cuypers H, Berghofer J, Zumft WG (1995) Multiple nosZ promoters and anaerobic expression of nos genes necessary for Pseudomonas stutzeri nitrous oxide reductase and assembly of its

46. Arai H, Mizutani M, Igarashi Y (2003) Transcriptional regulation of the nos genes for nitrous oxide reductase in Pseudomonas aeruginosa. Microbiology (Reading) 149: 29-36. doi: 10.1099/mic.0.25936-0

47. Zhao F, Zhou Z, Dang Y, Na H, Adam C, Lipzen A, Ng V, Grigoriev IV, Liu Y (2021) Genomewide role of codon usage on transcription and identification of potential regulators. Proc Natl 
TABLE:

456 Table1 General features of genomic information of DM15 and DM22

\section{FIGURES:}

458 Figure 1 The reducing $\mathrm{N}_{2} \mathrm{O}$ reduction rates of $P$. veronii DM15 and P. frederiksbergensis DM22 affected 459 by temperatures under anaerobic (A) and different oxygen concentrations at $30^{\circ} \mathrm{C}(\mathrm{B})$. Data represented 460 in mean \pm standard deviation $(\mathrm{n}=3)$ and small letters showed significance at $p<0.05$ level.

461 Figure 2 The abundance of nos $Z$ transcripts affected by temperatures under anaerobic (A) and different 462 oxygen concentrations at $30^{\circ} \mathrm{C}(\mathrm{B})$. Different letters represent significant differences at $p<0.05$ among 463 treatments $(n=3)$.

464 Figure 3 The gene numbers in COGs categories of $P$. veronii DM15 and P. frederiksbergensis DM22.

465 Figure 4 Composition of nitrogen cycling related genes of P. veronii DM15 (red solid box) and 466 P. frederiksbergensis DM22 (blue dotted box) based on the KEGG analysis.

467 Figure 5 Genome maps of nos clusters P. veronii DM15 (A) and P. frederiksbergensis DM22 (B), and 468 the CAI values (C) of nos cluster of the two Pseudomonas strains with $r p s R$ gene as reference.

469

470 SUPPLEMENTARY MATERIAL:

471 Figure S1 Scanning electron microscopy of strains $(10000 \times)$. DM15: P. veronii DM15; DM22:

472 P. frederiksbergensis DM22.

473

474 

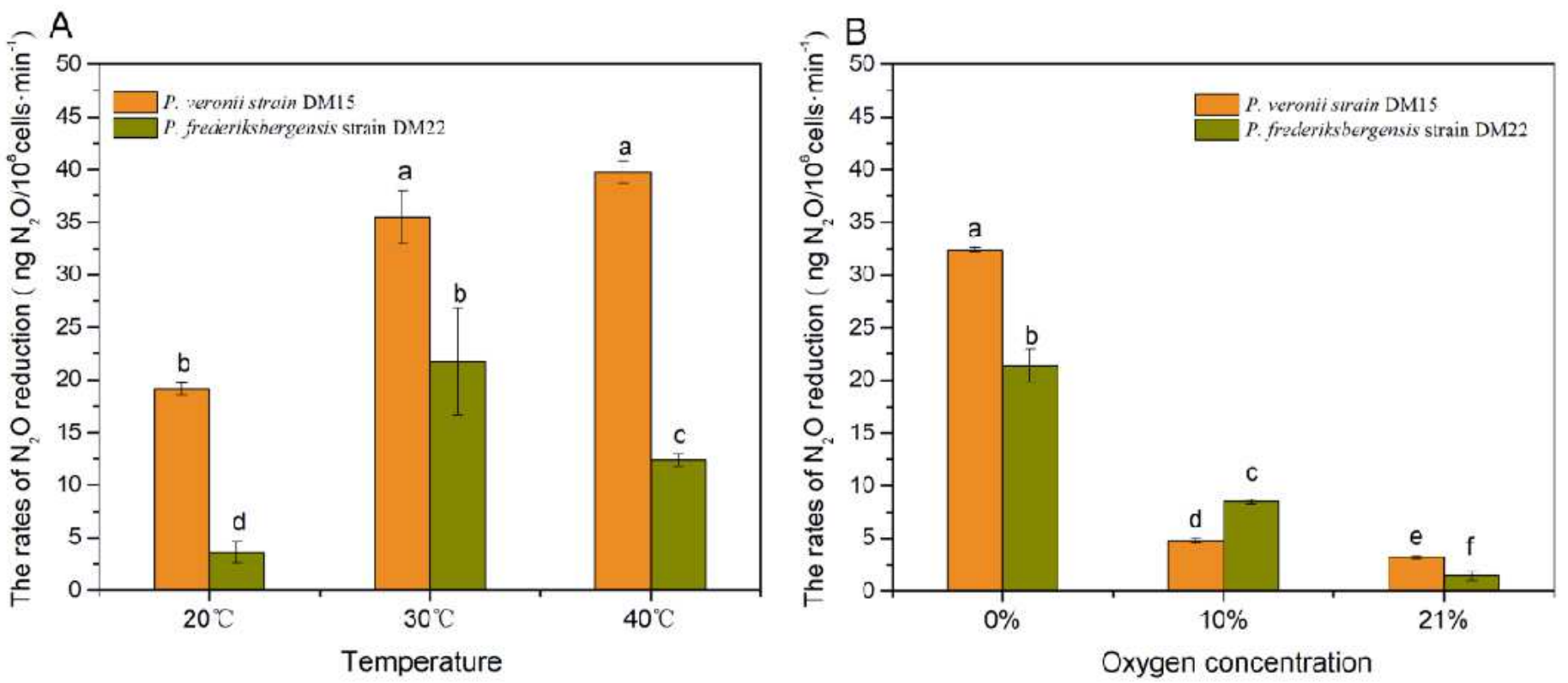

\section{Figure 1}

The reducing $\mathrm{N} 20$ reduction rates of P. veronii DM15 and P. frederiksbergensis DM22 affected by temperatures under anaerobic $(A)$ and different oxygen concentrations at $30^{\circ} \mathrm{C}(\mathrm{B})$. Data represented in mean \pm standard deviation $(n=3)$ and small letters showed significance at $p<0.05$ level.
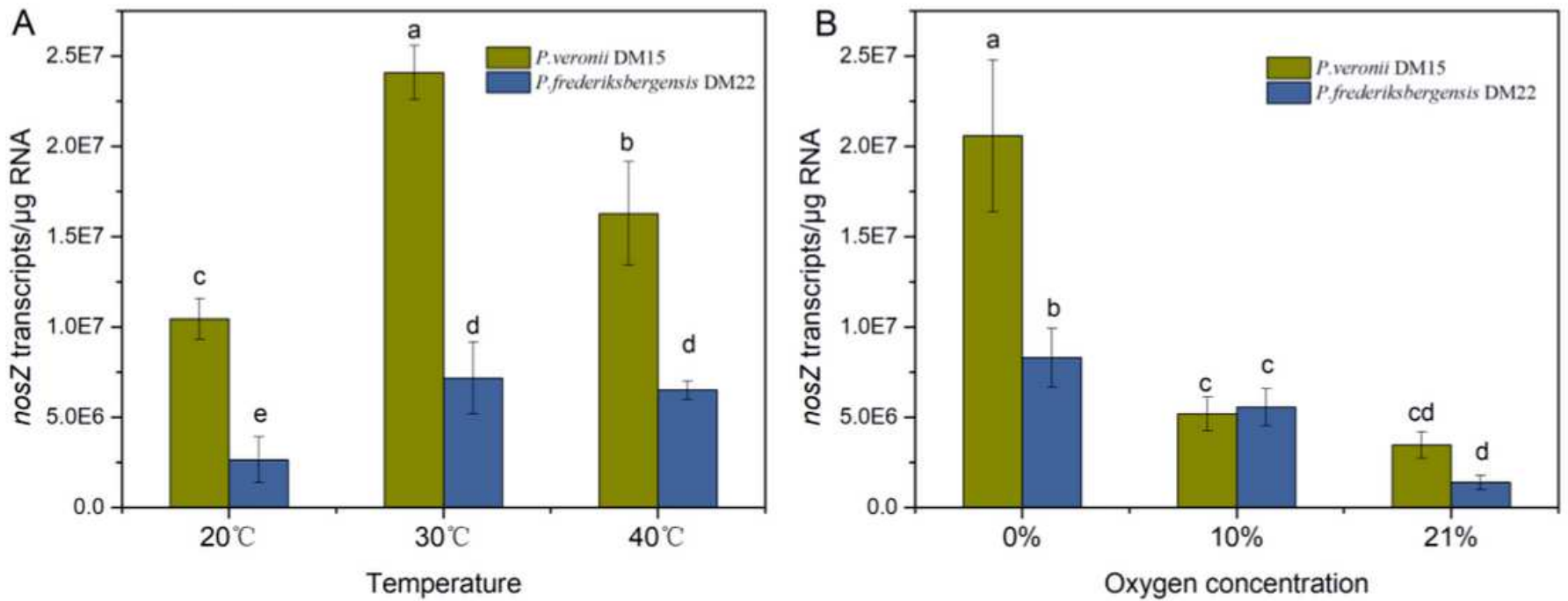

Figure 2

The abundance of nosZ transcripts affected by temperatures under anaerobic (A) and different oxygen concentrations at $30{ }^{\circ} \mathrm{C}(\mathrm{B})$. Different letters represent significant differences at $p<0.05$ among treatments $(n=3)$. 


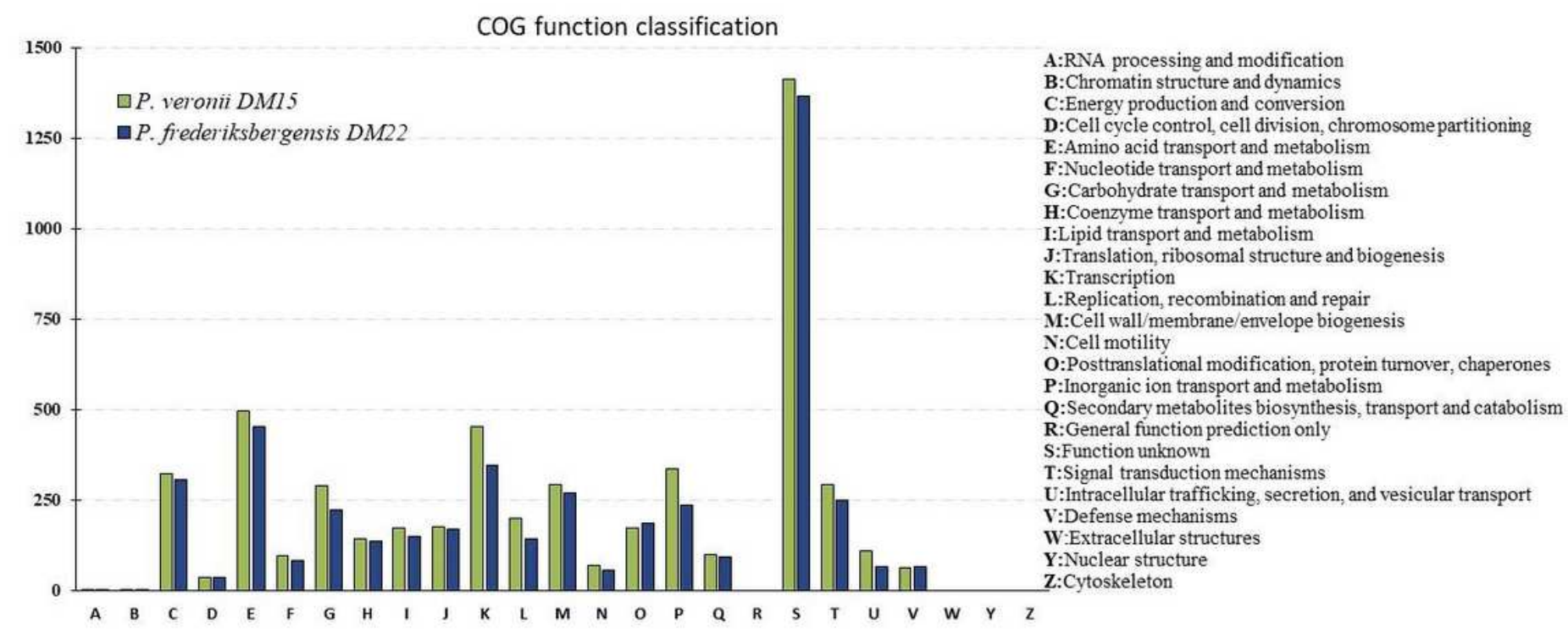

Figure 3

The gene numbers in COGs categories of P. veronii DM15 and P. frederiksbergensis DM22.

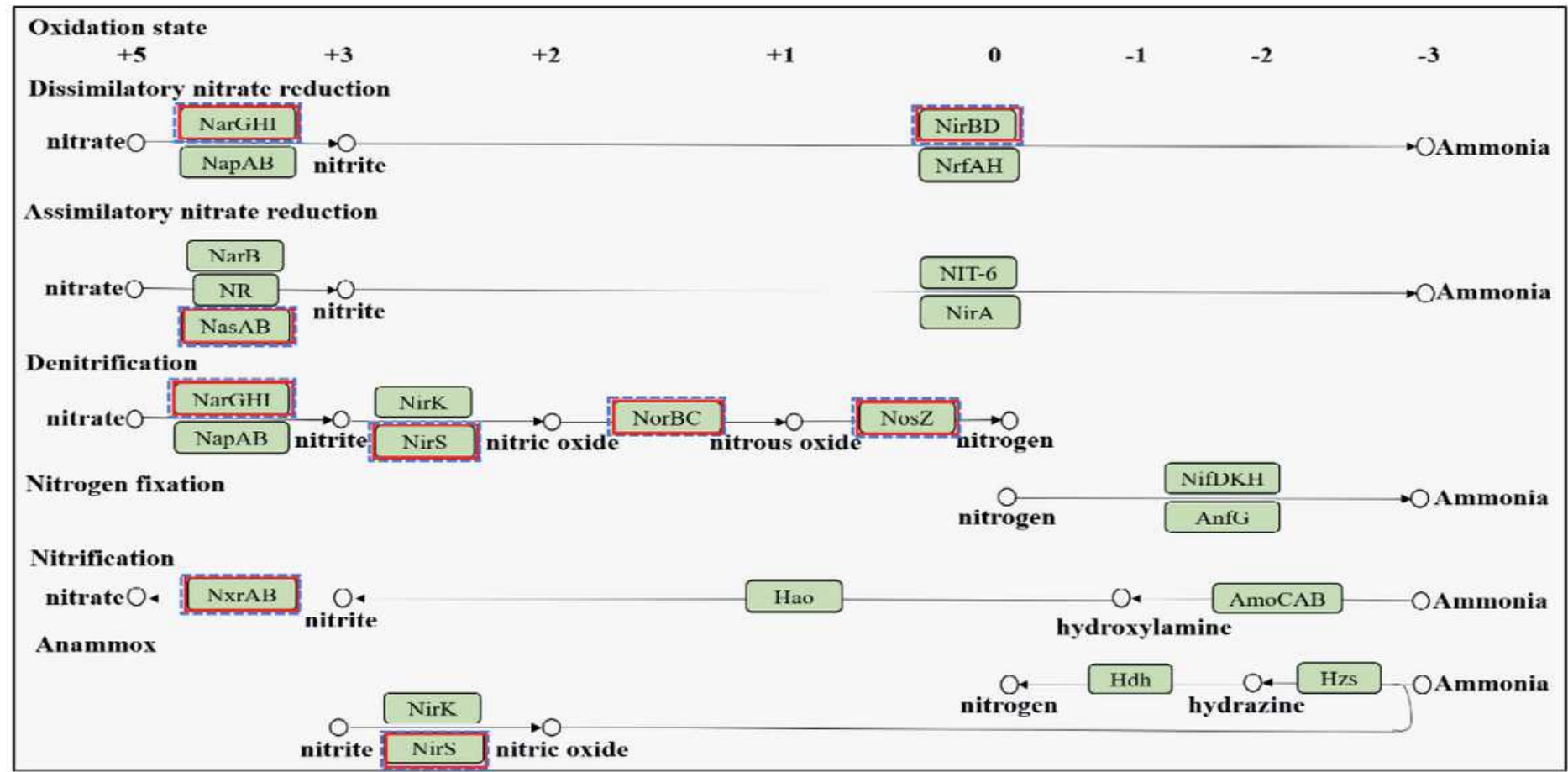

\section{Figure 4}

Composition of nitrogen cycling related genes of P. veronii DM15 (red solid box) and P. frederiksbergensis DM22 (blue dotted box) based on the KEGG analysis. 

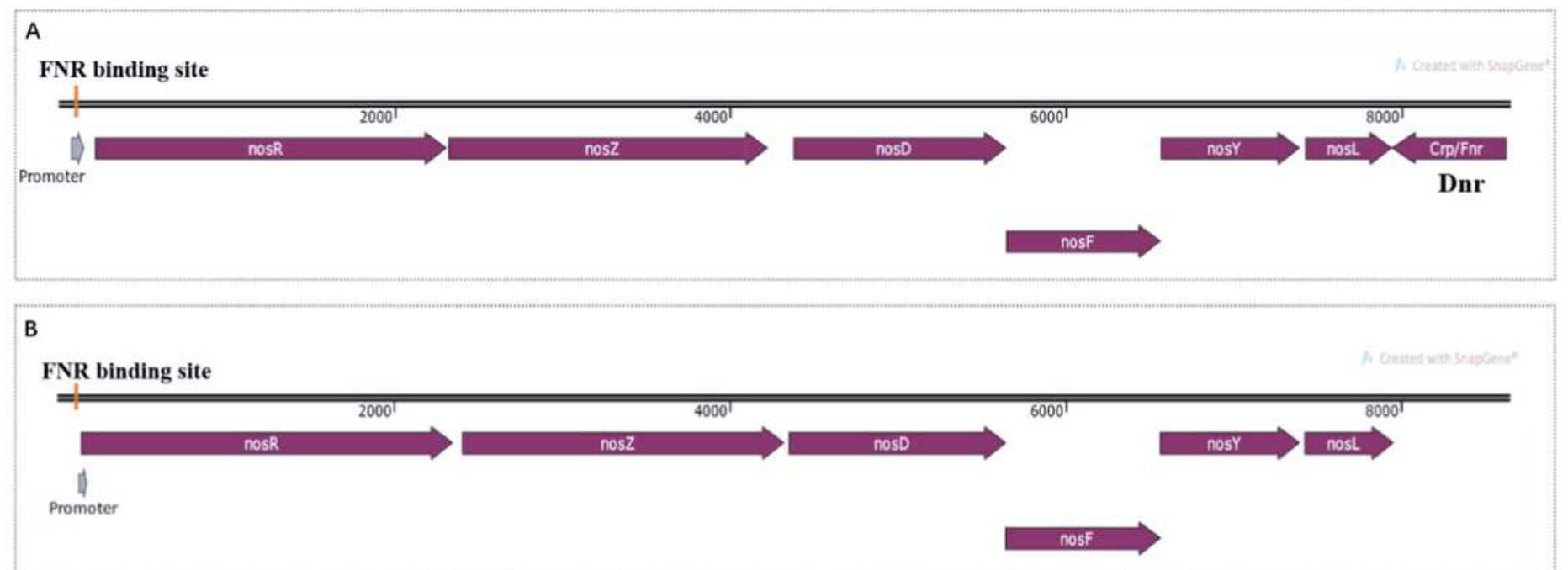

C

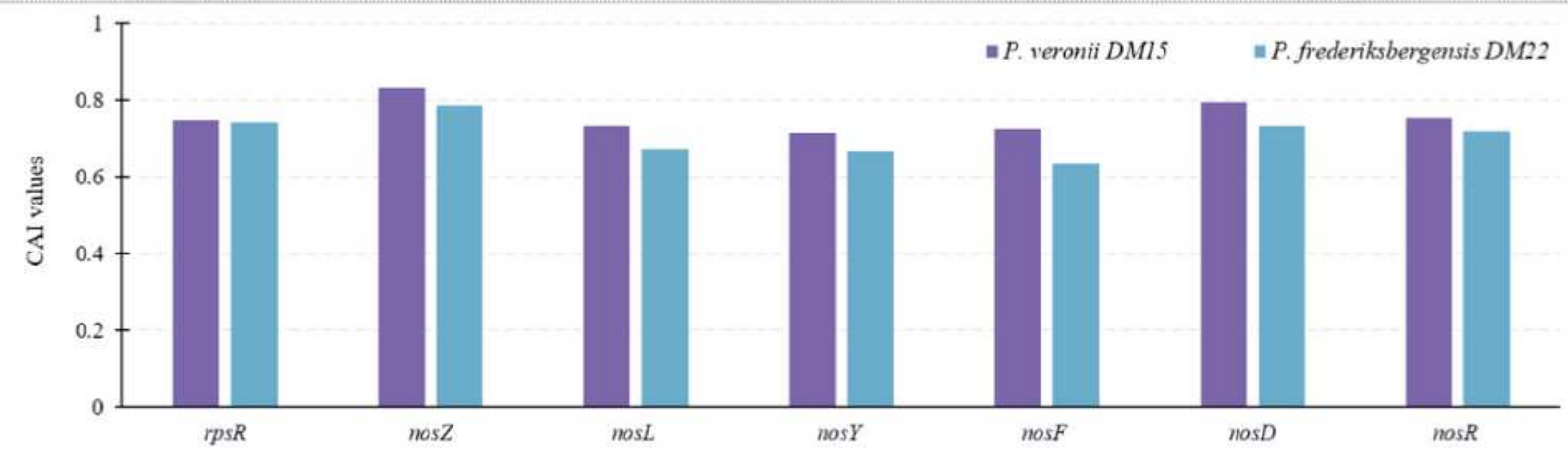

Figure 5

Genome maps of nos clusters P. veronii DM15 (A) and P. frederiksbergensis DM22 (B), and the CAl values (C) of nos cluster of the two Pseudomonas strains with rpsR gene as reference.

\section{Supplementary Files}

This is a list of supplementary files associated with this preprint. Click to download.

- Table.pdf

- Supplementarymaterial.pdf 